\title{
Phloretin Exerts Anti-Tuberculosis Activity and Suppresses Lung Inflammation
}

\author{
Dasom Jeon ${ }^{1}$, Min-Cheol Jeong ${ }^{1}$, Hum Nath Jnawali ${ }^{1}$, Chulhee Kwak ${ }^{1}$, Sungwon Ryoo ${ }^{2}$, \\ In Duk Jung ${ }^{3}$ and Yangmee Kim ${ }^{1, *}$ \\ 1 Department of Bioscience and Biotechnology, Konkuk University, Seoul 05029, Korea; \\ dasom921012@konkuk.ac.kr (D.J.); boby8520@konkuk.ac.kr (M.-C.J.); humnath@konkuk.ac.kr (H.N.J.); \\ chk90@konkuk.ac.kr (C.K.) \\ 2 Korean National Tuberculosis Association, Seoul 06763, Korea; viweon@naver.com \\ 3 Department of Immunology, School of Medicine, Konkuk University, Seoul 05029, Korea; jungid@kku.ac.kr \\ * Correspondence: ymkim@konkuk.ac.kr; Tel.: +82-2-450-3421; Fax: +82-2-447-5987
}

Academic Editor: Jean-Marc Sabatier

Received: 20 December 2016; Accepted: 18 January 2017; Published: 22 January 2017

\begin{abstract}
An increase in the prevalence of the drug-resistant Mycobacteria tuberculosis necessitates developing new types of anti-tuberculosis drugs. Here, we found that phloretin, a naturally-occurring flavonoid, has anti-mycobacterial effects on H37Rv, multi-drug-, and extensively drug-resistant clinical isolates, with minimum inhibitory concentrations of 182 and $364 \mu \mathrm{M}$, respectively. Since Mycobacteria cause lung inflammation that contributes to tuberculosis pathogenesis, anti-inflammatory effects of phloretin in interferon- $\gamma$-stimulated MRC-5 human lung fibroblasts and lipopolysaccharide (LPS)-stimulated dendritic cells were investigated. The release of interleukin (IL)-1 $\beta$, IL-12, and tumor necrosis factor (TNF)- $\alpha$ was inhibited by phloretin. The mRNA levels of IL-1 $\beta$, IL-6, IL-12, TNF- $\alpha$, and matrix metalloproteinase-1, as well as p38 mitogen-activated protein kinase and extracellular signal-regulated kinase phosphorylation, were suppressed. A mouse in vivo study of LPS-stimulated lung inflammation showed that phloretin effectively suppressed the levels of TNF- $\alpha$, IL-1 $\beta$, and IL-6 in lung tissue with low cytotoxicity. Phloretin was found to bind $M$. tuberculosis $\beta$-ketoacyl acyl carrier protein synthase III (mtKASIII) with high affinity $\left(7.221 \times 10^{7} \mathrm{M}^{-1}\right)$; a binding model showed hydrogen bonding of A-ring 2'-hydroxy and B-ring 4-hydroxy groups of phloretin with Asn261 and Cys122 of mtKASIII, implying that mtKASIII can be a potential target protein. Therefore, phloretin can be a useful dietary natural product with anti-tuberculosis benefits.
\end{abstract}

Keywords: phloretin; natural compound; Mycobacterium tuberculosis; antibiotics; inflammation

\section{Introduction}

Flavonoids are a class of polyphenolic compounds found in the human diet, mainly in fruits, vegetables, legumes, cereals, spices, nuts, and plant-derived foods, such as tea, coffee, and red wine. Dietary polyphenols exhibit a broad spectrum of pharmacological activities [1-3]; flavonoids are well-known for their antioxidant, anti-tumor, antimicrobial, antiviral, and anti-inflammatory activities [4]. Phloretin (3-(4-hydroxyphenyl)-1-(2,4,6-trihydroxyphenyl) propan-1-one) (Figure 1) is a dihydrochalcone with a $\mathrm{C} 6-\mathrm{C} 3-\mathrm{C} 6$ backbone. It is a natural compound abundant in apples (mostly in the peel) and in apple leaves, where it is present in either a free form or the glucosidic form phloridzin (phloretin 2'-O-glucose) [5-8]. Glycosylated derivatives of phloretin are mostly converted to the free form in the small intestine by hydrolytic enzymes [9]. Phloretin has many biological functions, including anti-oxidative and anti-cancer activities, and has been linked to the prevention of cardiovascular disease $[10,11]$. It was also shown to inhibit the production of inflammatory chemokines, cytokines, and differentiation factors induced by activated leukocytes in the innate 
immune response [12]. It was previously reported that phloretin treatment inhibits the expression of nuclear translocation of nuclear factor (NF)- $\mathrm{BB}$ subunit p65 and mitogen-associated protein kinase (MAPK) phosphorylation in LPS-stimulated RAW264.7 cells [13].

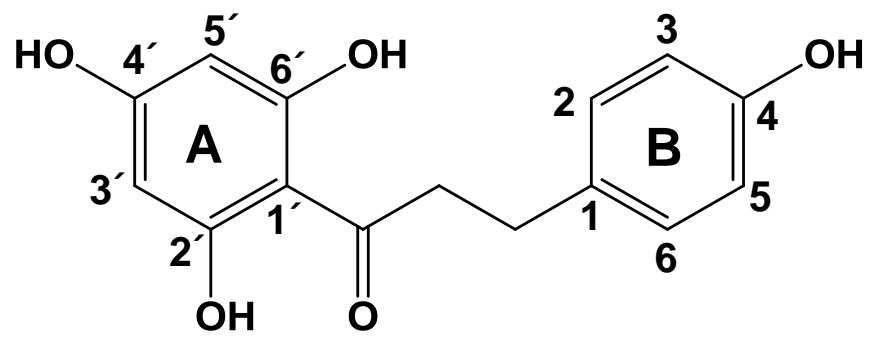

Figure 1. Chemical structure of phloretin.

Tuberculosis (TB) is an infection caused by Mycobacterium tuberculosis that primarily affects the lung, in which it infects and activates fibroblasts, macrophages, and dendritic cells [14]. TB can be characterized by considerable inflammation and development of granulomas. TB is, therefore, a chronic inflammatory condition in which regulatory and pro-inflammatory processes occur, either mutually or stage-wise, that contribute to the establishment and progression of disease. At least one-third of the world's population is infected with this bacterium, one of the leading infectious agents worldwide. In recent years, the control of TB has exerted pressure on chemotherapy regimens, resulting in the increasing prevalence of multidrug-resistant (MDR) and extensively drug-resistant (XDR) TB. It is, therefore, necessary to develop anti-tuberculosis drugs with enhanced activity against MDR and XDR strains, but also low toxicity, rapid mycobactericidal activity, and the ability to penetrate host cells for short-course therapy. The Mycobacteria cell wall, which is essential for its survival, is lipid-rich and highly impermeable, providing protection from antibiotics and allowing the bacterium to persist and to proliferate in macrophages [15]. Mycolic acids are long-chain $\alpha$-alkyl- $\beta$-hydroxy fatty acids that compose up to $60 \%$ of the Mycobacteria cell wall and are primarily responsible for the poor permeability of the waxy cell envelope [16]. Fatty acid biosynthesis is essential for the viability of pathogenic microorganisms and has recently emerged as a target of new therapeutic agents [17-19]. Mycobacteria are unusual in that they exhibit both type I and type II fatty acid synthases [20,21]. Type I synthases are single, multifunctional polypeptides that carry out all chain elongation reactions and are typically found in yeast and mammals, whereas type II systems-in which each chain elongation reaction is carried out by a discrete enzyme encoded by a separate gene- -are found in bacteria and plants [22]. $\beta$-ketoacyl-acyl carrier protein synthase III of M. tuberculosis (mtKASIII) links the fatty acid synthase I and II systems, catalyzing the condensation of fatty acid synthase I-derived acyl-coenzyme (Co)A with malonyl-acyl-carrier protein [23-25]. It is also a key condensing enzyme responsible for the initiation of type II fatty acid biosynthesis and is a potential target for novel anti-TB agents [26]. We previously reported on synthetic lead and natural compounds with broad-spectrum anti-bacterial activity as inhibitors of KAS III protein [27,28].

Though there has been great attention paid to natural products because of their beneficial effects on human health, there are no reports to date on the effects of phloretin on $M$. tuberculosis. For the first time, we investigated the anti-TB activities of phloretin. Since the anti-TB and anti-inflammatory effects gives a synergistic therapeutic effect to infection by M. tuberculosis, we examined the mode of action of phloretin in MRC-5 human lung fibroblasts stimulated with interferon (IFN)- $\gamma$, as well as LPS-stimulated dendritic cells. Since it has been known that dendritic cells infected by Mycobacteria produces large quantities of immunosuppressive cytokines, such as interleukin (IL)- $1 \beta$, tumor necrosis factor (TNF)- $\alpha$, and IL-6, we investigate how phloretin suppresses inflammation on LPS-stimulated dendritic cells, too [14,29]. KASIII is known as a potential target for novel anti-bacterial agents because it is an important enzyme for the initiation of type II fatty acid biosynthesis [22-24]. We discussed the 
structure-activity relationships of phoretin related to anti-TB activities and assessed the interactions between phloretin and mtKASIII, a potential target protein by molecular docking and fluorescence quenching studies. Furthermore, we investigated the in vivo effect of phloretin in a mouse model of LPS-induced lung inflammation. The results confirmed the benefits of phloretin as a dietary natural compound for the suppression of TB and associated lung inflammation.

\section{Results and Discussion}

\subsection{Anti-TB Activities of Phloretin}

Phloretin is a natural food product, present in apple and strawberries that may improve acute and chronic disease [11]. Apples are known to inhibit colon, lung, and prostate cancers [30], to improve lung function, and to decrease the risk of respiratory diseases, such as chronic obstructive pulmonary disease [31]. In the present study, we investigated for the first time that phloretin has anti-mycobacterial activities against $M$. tuberculosis strain H37Rv and MDR and XDR clinical isolates, and also suppresses lung inflammation. Phloretin inhibited the growth of strain H37Rv, with a MIC 90 (lowest concentration to produce $90 \%$ inhibition of $M$. tuberculosis growth) of $182 \mu \mathrm{M}$, and MDR (M22) and XDR (X24 and X59) isolates at $\mathrm{MIC}_{90}=364 \mu \mathrm{M}$ (Figure 2A-D). Therefore, phloretin may potentially be taken with conventional anti-TB drugs to protect against TB. Recently, we demonstrated that the natural flavonoid isorhamnetin, which is abundant in apples, cherries, and blackberries, showed anti-TB activity against M. tuberculosis H37Rv, multi-drug- and extensively drug-resistant clinical isolates, too [32]. Therefore, natural flavonoids may be a good source of anti-TB agents.
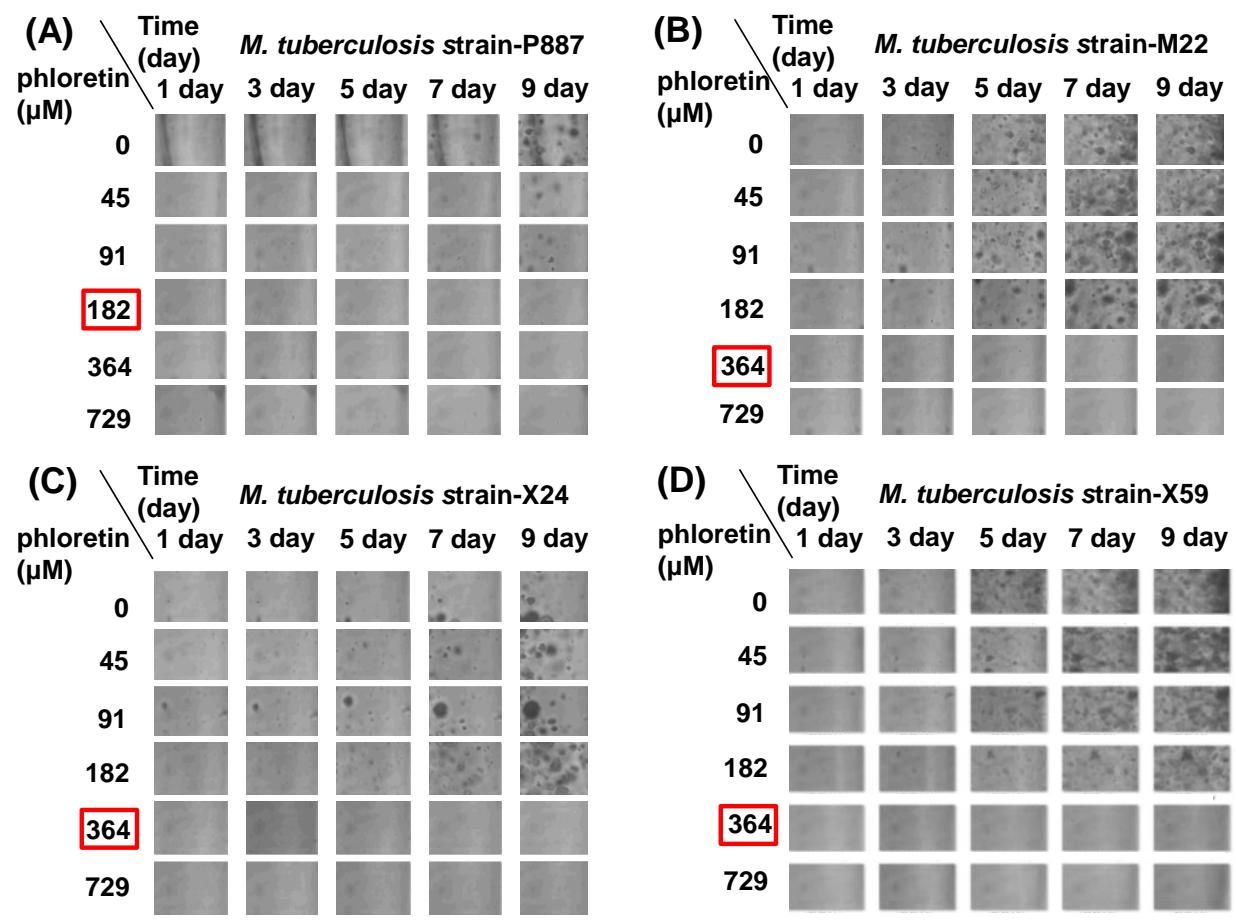

Figure 2. Effects of phloretin on the growth of (A) M. tuberculosis P887 (H37Rv); (B) M. tuberculosis M22 (multidrug resistant); (C) M. tuberculosis X24 (extensively drug resistant); and (D) M. tuberculosis X59 (extensively drug resistant) strains. Red squares denote the $\mathrm{MIC}_{90}$ for each strain.

\subsection{Effects of Phloretin on mRNA Expression of Inflammatory Cytokines in IFN- $\gamma$-Stimulated MRC-5 Cells} and in LPS-Stimulated Dendritic Cells

IFN- $\gamma$ is a cytokine produced by activated T cells and natural killer cells; it is one of the major cytokines responsible for activating macrophages and induces inflammation via nitric oxide synthase, 
cyclooxygenase-2, IL-1 $\beta$, and IL-12 upregulation and activation [33,34]. M. tuberculosis infection occurs primarily in the lungs and lymph nodes and is characterized by the formation of granulomas [35], which are organized immune cell structures consisting of macrophages, fibroblasts, neutrophils, and lymphocytes [36,37]. Fibroblasts in connective tissue can be infected by and support the replication of M. tuberculosis [38], which can interact with cells of the innate and adaptive immune systems, inducing the secretion of chemokines and cytokines, including IL-1 $\beta$, IL-6, IFN- $\gamma$, IL-12, and TNF- $\alpha$.

To clarify the mechanism by which phloretin suppresses inflammation induced by IFN- $\gamma$ on human lung fibroblast MRC-5 cells, we examined the mRNA expression of factors downstream of IFN- $\gamma$-including the inflammatory cytokines IL-1 $\beta$, IL-6, IL-12, and TNF- $\alpha$, as well as matrix metalloproteinase (MMP)-1-by reverse transcription-polymerase chain reaction (RT-PCR). IFN- $\gamma$ induced an upregulation of these factors after $3 \mathrm{~h}$, whereas pretreatment with phloretin decreased the levels of TNF- $\alpha$, IL-1 $\beta$, IL-6, IL-12, and MMP-1 by 55\%, 48\%, 97\%, 100\%, and 100\%, respectively, as compared to the levels in untreated cells (Figure 3A).
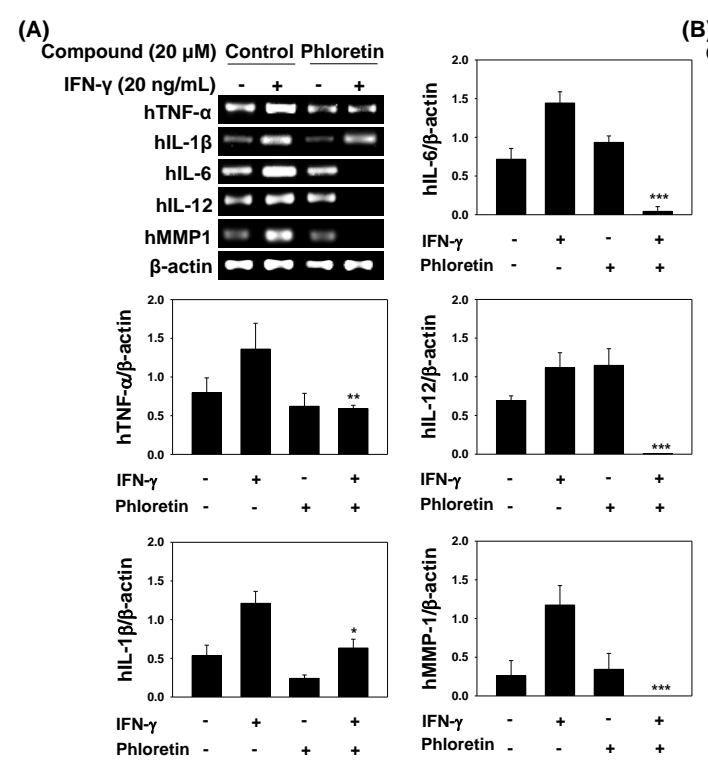

(B) Compound $(20 \mu \mathrm{M})$ Control Phloretin
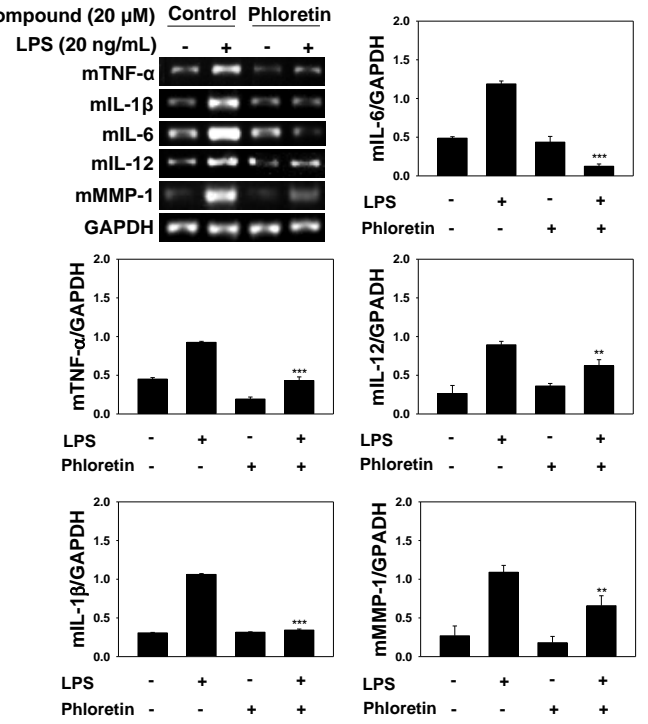

Figure 3. Effects of phloretin on mRNA expression of inflammatory cytokines (A) tumor necrosis factor (TNF)- $\alpha$, interleukin (IL)-1 $\beta$, IL-6, IL-12, matrix metalloproteinase (MMP)-1, and $\beta$-actin in interferon (IFN)- $\gamma$-treated MRC-5 cells and their quantitative analysis of reverse transcription polymerase chain reaction results; and (B) TNF- $\alpha$, IL-1 $\beta$, IL-6, IL-12, MMP-1, and Glyceraldehyde 3-phosphate dehydrogenase (GAPDH) in LPS-treated dendritic cells and their quantitative analysis of reverse transcription polymerase chain reaction results. Cells were untreated (negative control) or stimulated with $20 \mathrm{ng} / \mathrm{mL}$ IFN- $\gamma$ for MRC-5 cells and $20 \mathrm{ng} / \mathrm{mL}$ LPS for dendritic cells in the presence or absence of phloretin for $3 \mathrm{~h}$. Relative expression was quantified using ImageJ, and bars represent mean expression level \pm standard deviation relative to $\beta$-actin for IFN- $\gamma$-treated MRC- 5 cells and GAPDH for LPS-treated dendritic cells. ${ }^{*} p<0.05,{ }^{* *} p<0.005,{ }^{* * *} p<0.001$ vs. cells treated with IFN- $\gamma$ or LPS only.

M. tuberculosis infection also activates dentritic cells and increases production of cytokines, such as TNF- $\alpha$, IL-1 $\beta$, IL-6, and IL-12p70 [14,29]. Therefore, we examined the mRNA expression of the inflammatory cytokines IL-1 $\beta$, IL-6, IL-12, and TNF- $\alpha$, and MMP-1 in LPS-stimulated dendritic cells by RT-PCR. Pretreatment with phloretin decreased the levels of TNF- $\alpha$, IL-1 $\beta$, IL-6, IL-12, and MMP-1 by $53 \%, 68 \%, 90 \%, 30 \%$, and $40 \%$, respectively, as compared to the levels in untreated cells (Figure 3B). 


\subsection{Effects of phloretin on IFN- $\gamma-$ Induced Protein Expression}

In order to understand the signaling pathways activated by Mycobacteria, we investigated the effects of phloretin on the phosphorylation status of c-Jun N-terminal kinase (JNK), p38 MAPK, and extracellular signal-regulated kinase (ERK) in MRC- 5 cells stimulated with IFN- $\gamma$. Phloretin reduced the phosphorylation of JNK, p38 MAPK, and ERK to 13\%, 44\%, and 53\%, respectively (Figure 4A-D).

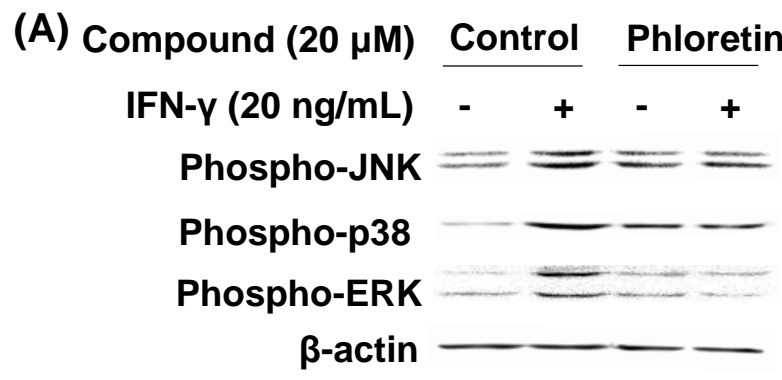

(C)

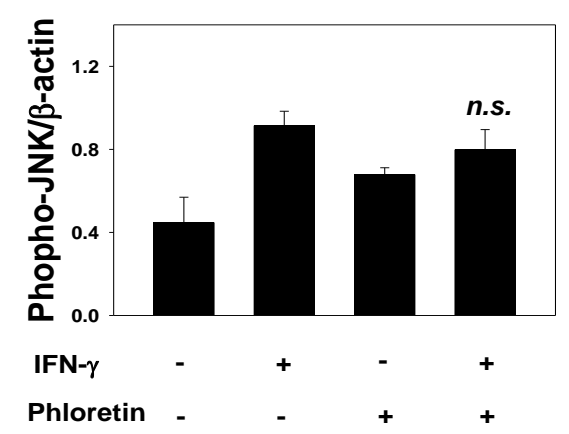

(B)

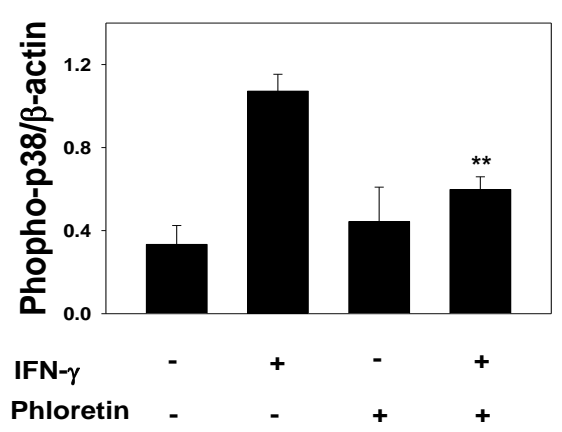

(D)

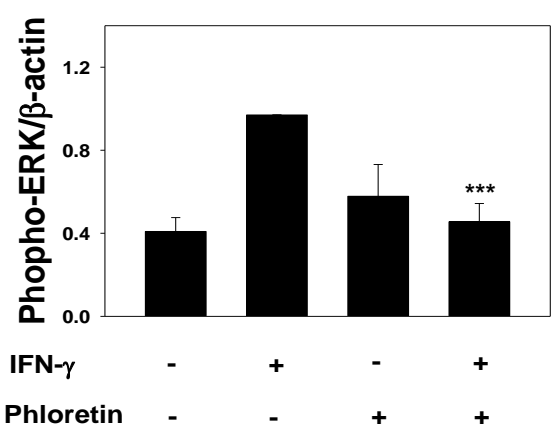

Figure 4. JNK, p38 MAPK, and ERK expression in MRC-5 cells pretreated with phloretin and stimulated with interferon (IFN)- $\gamma$. (A) MAPK levels were evaluated by Western blot, with $\beta$-actin used as a loading control; (B-D) relative intensities of phosphorylated JNK, p38 MAPK, and ERK normalized to $\beta$-actin, respectively. Data represent mean \pm standard deviation. ${ }^{* *} p<0.005,{ }^{* * *} p<0.001$ vs. cells treated with IFN- $\gamma$ only.

\subsection{Inflammatory Cytokine Levels in INF- $\gamma$-Stimulated MRC-5 Cells and LPS-Stimulated Dendritic Cells}

We also examined the effects of phloretin on TNF- $\alpha$, IL-1 $\beta$, and IL-12 secretion in MRC- 5 cells stimulated with $20 \mathrm{ng} / \mathrm{mL}$ INF- $\gamma$ (Figure 5A-C). At 10 and $20 \mu \mathrm{M}$ concentrations, phloretin suppressed IL-1 $\beta$ production by $39 \%$ and $45 \%$ respectively (Figure $5 \mathrm{~A}$ ), IL-12 levels by $35 \%$ and $56 \%$, respectively (Figure $5 \mathrm{~B}$ ), and TNF- $\alpha$ production by $43 \%$ and $57 \%$ respectively (Figure $5 \mathrm{C}$ ), as compared to cells that did not receive phloretin treatment. We then measured the effects of phloretin on TNF- $\alpha$, IL-1 $\beta$, and IL-6 secretion in dendritic cells stimulated with $20 \mathrm{ng} / \mathrm{mL}$ LPS (Figure 5D-F). At 10 and $20 \mu \mathrm{M}$, phloretin suppressed IL-1 $\beta$ production by $37 \%$ and $69 \%$, respectively (Figure 5D); IL-6 levels by $22 \%$ and $68 \%$, respectively (Figure $5 \mathrm{E}$ ); and TNF- $\alpha$ production by $45 \%$ and $85 \%$, respectively (Figure $5 \mathrm{~F}$ ), as compared to cells without phloretin treatment. 

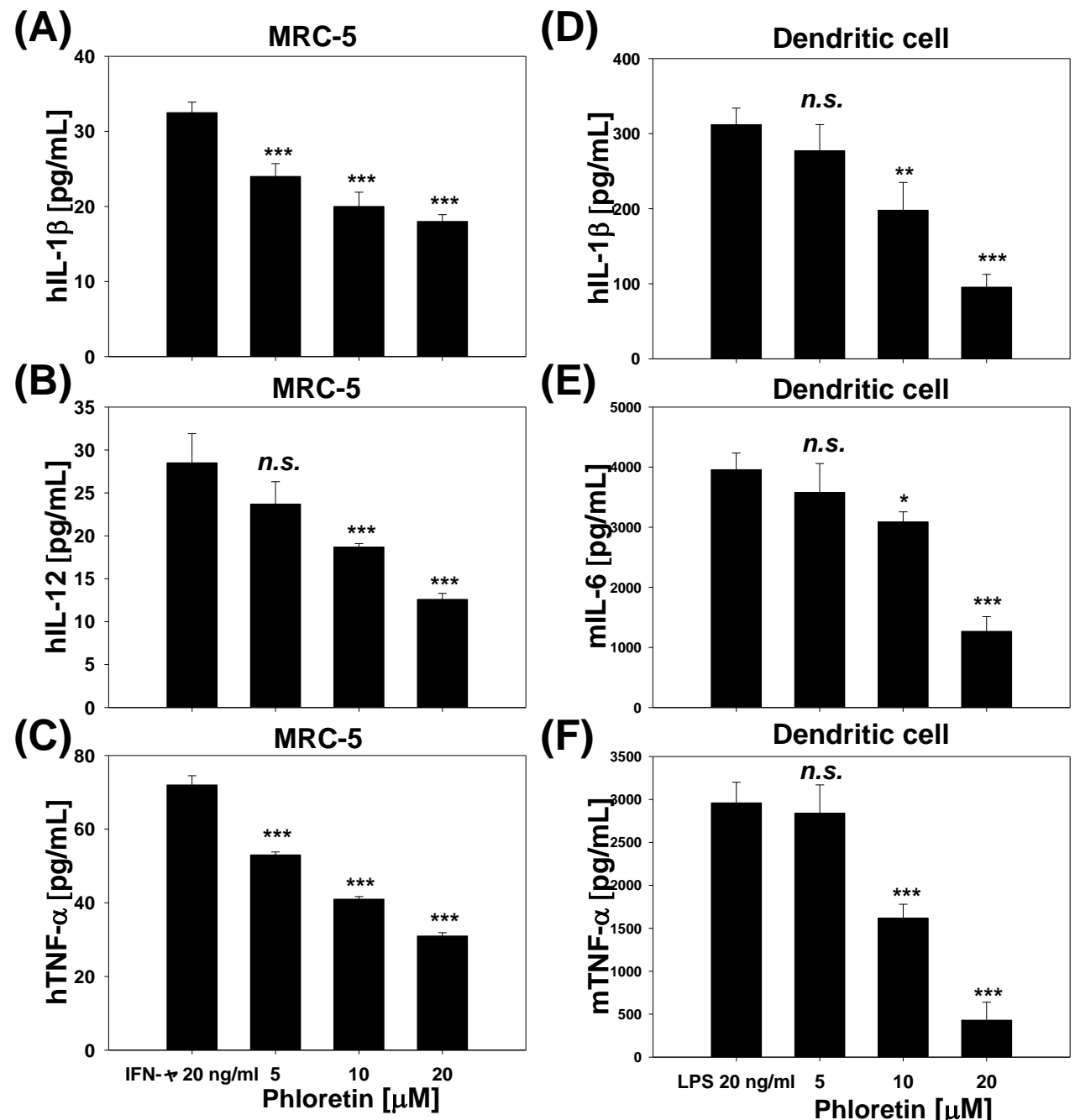

(E)

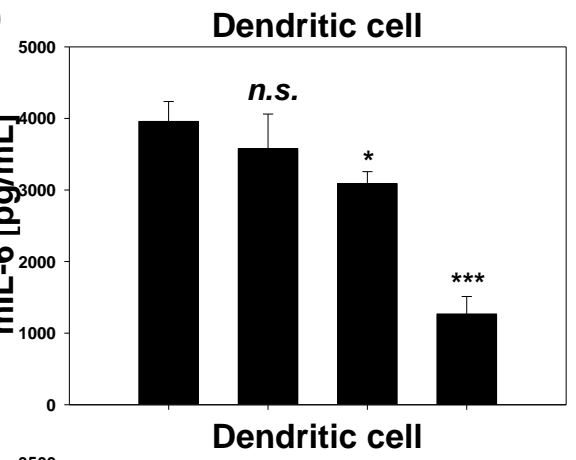

(F)

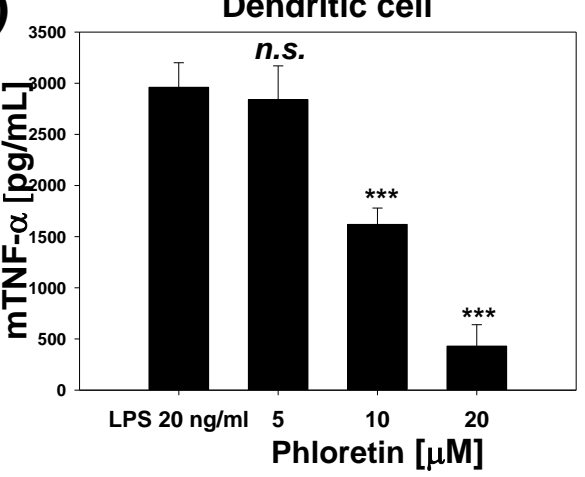

Figure 5. Levels of (A) interleukin (IL)-1 $\beta$; (B) IL-12; and (C) tumor necrosis factor (TNF)- $\alpha$ in the culture medium of interferon (INF)- $\gamma$-stimulated MRC-5 cells; and (D) IL-1 $\beta$; (E) IL-6; and (F) tumor necrosis factor (TNF)- $\alpha$ in the culture medium of lipopolysaccharide-stimulated dendritic cells treated with indicated concentrations of phloretin for $24 \mathrm{~h}$. Data represent mean \pm standard deviation of three independent experiments. ${ }^{*} p<0.05,{ }^{* *} p<0.005,{ }^{* * *} p<0.001$ vs. cells treated with IFN- $\gamma$ only (A-C) or LPS only (D-F).

\subsection{TNF- $\alpha, I L-1 \beta$, and IL-6 Levels in LPS-Stimulated Mouse Lung Tissue}

In order to demonstrate the potency of phloretin as an anti-inflammatory agent in lung inflammation, we investigated the effects of phloretin on inflammation in vivo. We measured the effect of phloretin on the production of pro-inflammatory cytokines TNF- $\alpha$, IL- $1 \beta$, and IL- 6 in lung homogenates from $10 \mathrm{mg} / \mathrm{kg}$ LPS-stimulated mice (Figure 6). At 2.5 and $5 \mathrm{mg} / \mathrm{kg}$, phloretin inhibited TNF- $\alpha$ production in vivo by $11 \%$ and $56 \%$, respectively (Figure 6 A); IL- $1 \beta$ by $6 \%$ and $19 \%$, respectively (Figure 6B); and IL-6 by $26 \%$ and $28 \%$ (Figure 6C), respectively. 


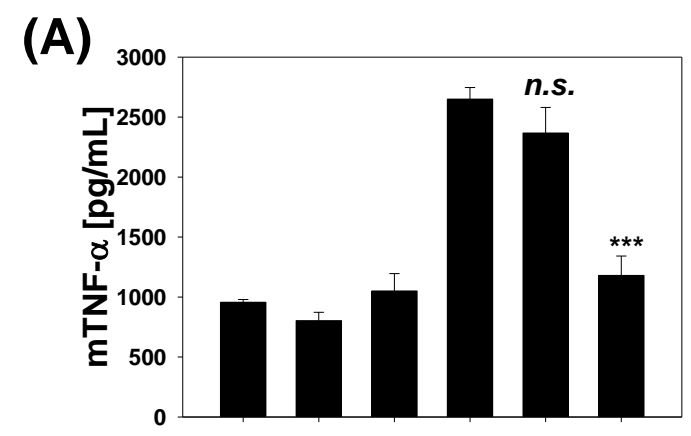

(B)

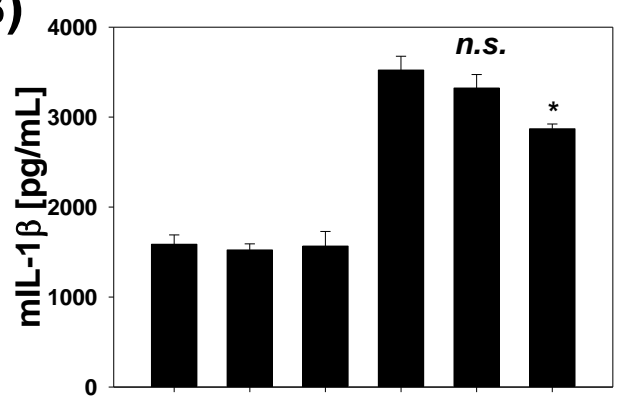

(C)

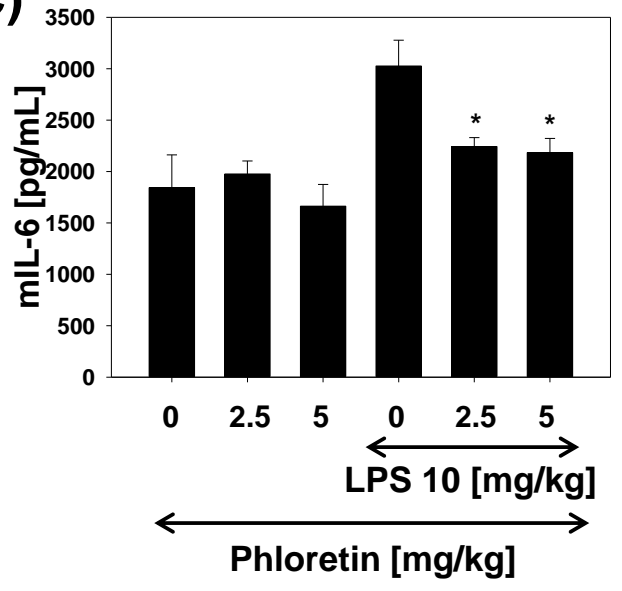

Figure 6. Inhibition of the pro-inflammatory cytokines (A) tumor necrosis factor (TNF)- $\alpha$; (B) interleukin (IL)-1 $\beta$; and (C) IL-6, in a mouse model of lipopolysaccharide (LPS)-stimulated lung inflammation. ${ }^{*} p<0.05,{ }^{* * *} p<0.001$ vs. cells treated with LPS only.

\subsection{Cytotoxicity of Phloretin in Mammalian Cells and in LPS-Stimulated Mice}

We examined the toxicity of phoretin in mammalian cells (MRC-5 and HaCaT cells) with the 3-(4,5-dimethylthiazol-2-yl)2,5-diphenyl tetrazolium bromide (MTT) assay. Phloretin concentrations of up to $100 \mu \mathrm{M}$ did not affect the viability of MRC-5 cells (Figure 7A); even at concentrations of $400 \mu \mathrm{M}$, viability was $>50 \%$ in MRC- 5 cells. On the other hand, the survival of HaCaT non-cancerous human keratinocytes was unaffected up to $150 \mu \mathrm{M}$; viability was $>75 \%$, even at concentrations of up to $400 \mu \mathrm{M}$. At its $\mathrm{MIC}_{90}(182 \mu \mathrm{M})$ against M. tuberculosis-P887 strain, survival rates of HaCaT cells and MRC-5 cells were $93 \%$ and $78 \%$, respectively, while at its MIC $_{90}(364 \mu \mathrm{M})$ against MDR and XDR strains, cell survival rates were $76 \%$ and $55 \%$, respectively.

We also investigated the in vivo toxicity of phloretin by measuring serum alanine transaminase, aspartate aminotransferase, and blood urea nitrogen levels. We found that the levels of these blood parameters in mice treated with 2.5 or $5 \mathrm{mg} / \mathrm{kg}$ phloretin were not significantly different from those in mice treated with LPS only (Figure 7B-D). In addition, the phloretin-treated mice did not show visible signs of toxicity, such as weight loss, twisting, irritability, or death. 
(A)

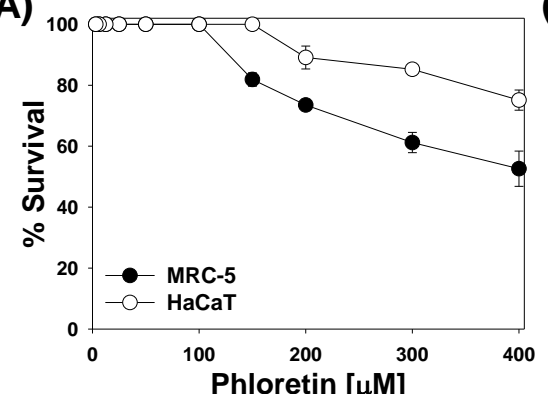

(C)

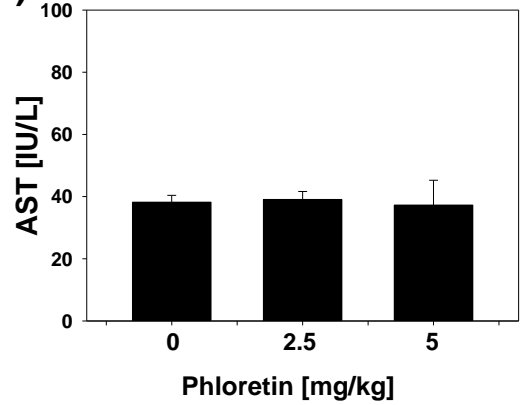

(B)

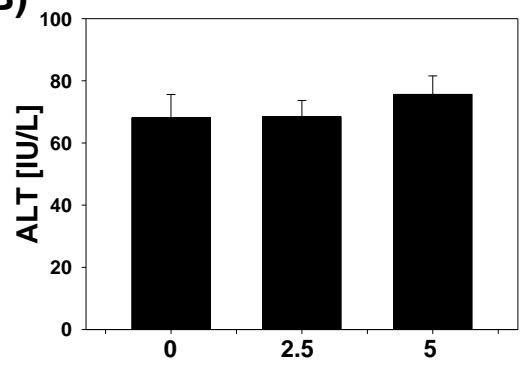

(D)

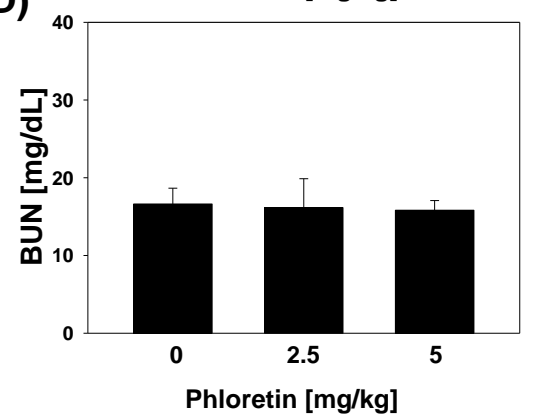

Figure 7. (A) Cell viability upon treatment with phloretin. MRC-5 human lung fibroblasts and $\mathrm{HaCaT}$ non-cancerous human keratinocytes were treated with phloretin for $24 \mathrm{~h}$ and viability was assessed with the 3-(4,5-dimethylthiazol-2-yl)2,5-diphenyl tetrazolium bromide (MTT) assay; the effects of phloretin on serum levels of (B) alanine transaminase (ALT); (C) aspartate aminotransferase (AST); and (D) blood urea nitrogen (BUN). Data represent mean \pm standard deviation.

\subsection{Phloretin-mtKASIII Binding Affinity and Docking Study of Phloretin with mtKASIII}

In order to find the possible target protein for anti-TB activity of phloretin, we investigated the interaction between phloretin and mtKASIII. mtKASIII is a key condensing enzyme responsible for the initiation of type II fatty acid biosynthesis and can be a potential target for novel anti-TB agents. The fluorescence titration curves for mtKASIII with phloretin indicated that the tryptophan fluorescence of mtKASIII was significantly quenched in the presence of phloretin (Figure 8). Phloretin bound tightly to mtKASIII with a binding affinity of $7.221 \times 107 \mathrm{M}^{-1}$.

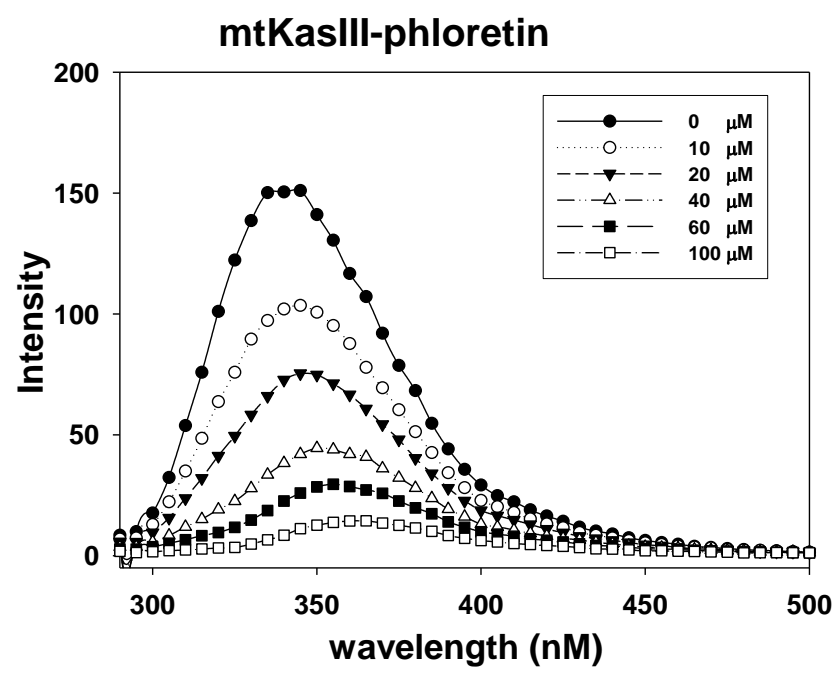

Figure 8. Fluorescence spectra of mtKASIII in the presence of $0,10,20,40,60$, and $100 \mu \mathrm{M}$ phloretin at $\mathrm{pH}$ 7.0. Samples were excited at $290 \mathrm{~nm}$, and emission spectra were recorded at 290-600 nm. 
A docking analysis revealed hydrogen bonding networks between the Asn261 of mtKASIII and the 2'-hydroxy groups of the A-ring of phloretin and between the Cys122 of mtKASIII and the $4^{\prime}$-hydroxy groups of the B-ring of phloretin (Figure 9). The B-ring of phloretin formed additional hydrophobic interactions with Ile166, Ile199, Leu221, Val226, and Ala260 of mtKAS III. Our current results indicate that phloretin exhibited strong binding to mtKASIII, mainly via hydrogen bonding and hydrophobic interactions, which may contribute to the inhibition of initial type II fatty acid elongation step by mtKASIII in M. tuberculosis. These results confirmed that mtKASIII can be a potential target for novel anti-TB agents.

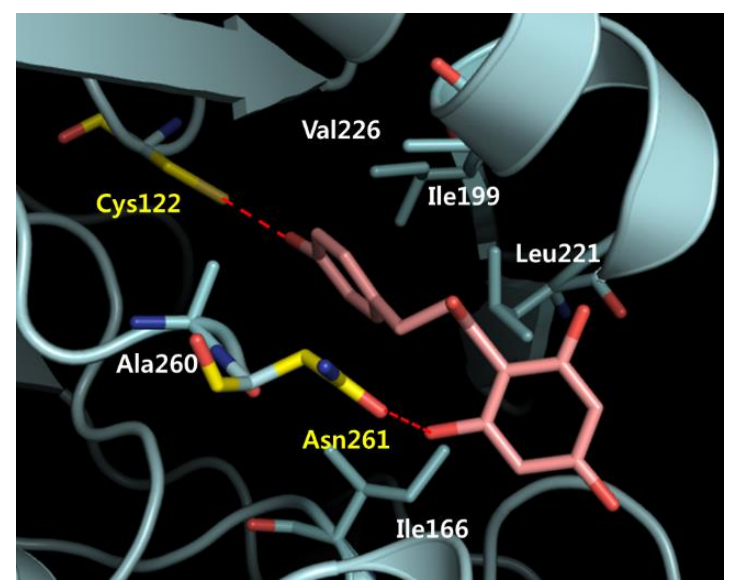

Figure 9. Binding of phloretin and mtKASIII. Hydrophobic residues and those participating in hydrogen bonding are shown in white and yellow, respectively.

\section{Materials and Methods}

\subsection{Phloretin}

Phloretin was purchased from Sigma-Aldrich (St. Louis, MO, USA) and the purity was determined to be $99 \%$ by high-performance liquid chromatography. The chemical was dissolved in dimethylsulfoxide to obtain a $10 \mathrm{mg} / \mathrm{mL}$ stock solution.

\subsection{Evaluation of Anti-TB Activity}

The anti-tuberculosis activity of phloretin against MDR and XDR M. tuberculosis H37Rv strains was determined as previously described [32]. Briefly, the culture broth $(166 \mu \mathrm{L})$ of M. tuberculosis H37Rv, MDR, and XDR clinical isolates was combined at $37^{\circ} \mathrm{C}$ with $500 \mu \mathrm{L}$ of $0.5 \%$ liquid agarose. A $10 \mu \mathrm{L}$ volume of this mixture was loaded into an inlet well to form microfluidic agarose channels. The bacteria were immobilized when the gel solidified at room temperature. Phloretin $(0-729 \mu \mathrm{M})$, the positive control isoniazid (0-16 $\mu \mathrm{M}$, Sigma-Aldrich), and Middlebrook 7H9 broth containing $10 \%$ oleic albumin dextrose catalase were loaded onto the gel; the compounds and culture medium diffused towards the microfluidic agarose channels. The 96-well microfluidic agarose channel chip was incubated at $37^{\circ} \mathrm{C}$ and the boundary area between the liquid medium loading well and microfluidic agarose channel was imaged at 1,3,5,7, and 9 days on an inverted microscope using a $40 \times$ objective lens. Bacterial growth was determined from the images. The dark grey spots corresponding to M. tuberculosis strains in time-lapse images were converted to digital information by image processing. Susceptibility to the agent was determined by evaluating the area of $M$. tuberculosis coverage and calculating the lowest concentration inhibiting $M$. tuberculosis growth by $90 \%\left(\mathrm{MIC}_{90}\right)$. All assays were performed at least three times. 


\subsection{Reverse Transcription-Polymerase Chain Reaction}

Human lung fibroblast MRC-5 cells were purchased from the American Type Culture Collection (Manassas, VA, USA). Human lung fibroblast MRC-5 cells were stimulated with or without $20 \mathrm{ng} / \mathrm{mL}$ IFN- $\gamma$ in the presence or absence of phloretin for $3 \mathrm{~h}$. Dendritic cells were stimulated with or without $20 \mathrm{ng} / \mathrm{mL}$ LPS in the presence or absence of phloretin for $3 \mathrm{~h}$. The mRNA expression of IL-1 $\beta$, IL-6, hIL-12, TNF- $\alpha$, MMP-1, $\beta$-actin, and GAPDH (Glyceraldehyde 3-phosphate dehydrogenase) was evaluated by RT-PCR using previously-reported primers [32]. Signal intensity was quantified by densitometry using ImageJ software (National Institutes of Health, Bethesda, MD, USA) [39].

\subsection{Western Blot}

Equal amounts of protein $(20 \mu \mathrm{g})$ isolated from MRC-5 cells were electrophoretically separated on $10 \%$ sodium dodecyl sulfate polyacrylamide gels and then transferred to polyvinylidene difluoride membranes [32] that were blocked and incubated with primary antibodies against phosphorylated JNK, phosphorylated ERK, phosphorylated p38, and $\beta$-actin at $4{ }^{\circ} \mathrm{C}$ overnight [40]. After washing three times with tris-buffered saline containing Tween 20 , the membranes were incubated with horseradish peroxidase-conjugated secondary antibodies at room temperature for $4 \mathrm{~h}$, followed by incubation with Luminol/Enhancer solution. The relative density of protein bands was quantified using ImageJ software.

\subsection{Enzyme-Linked Immunosorbent Assay}

The inhibitory effect of phloretin on inflammatory cytokine production was evaluated in MRC-5 human lung fibroblasts as well as LPS-stimulated dendritic cells by enzyme-linked immunosorbent assay (ELISA). Inflammatory cytokine levels were calculated based on a standard curve using recombinant cytokines provided in the ELISA kits as previously described [41]. Values are reported as the mean \pm standard deviation of at least three independent experiments.

\subsection{In Vivo Mouse Model of LPS-Stimulated Lung Inflammation}

BALB/c mice where phloretin exerts anti-tuberculosis activity and suppresses lung inflammation assigned to six experimental groups, with three mice in each group. Samples were prepared in phosphate-buffered saline. Mice were pre-administered phloretin $(2.5 \mathrm{or} 5 \mathrm{mg} / \mathrm{kg})$ by intraperitoneal injection. After $1 \mathrm{~h}$, the mice received another intraperitoneal injection with $10 \mathrm{mg} / \mathrm{kg}$ LPS and were retained for $12 \mathrm{~h}$ before sacrifice. After centrifuging the lung homogenates at 13,000 rpm for $15 \mathrm{~min}$ at $4{ }^{\circ} \mathrm{C}$, the supernatants were measured by ELISA as described previously [32]. Serum alanine transaminase and aspartate aminotransferase were analyzed using the Reitman-Frankel method as follows: The substrate reagent and serum were co-incubated for $60 \mathrm{~min}$ at $37^{\circ} \mathrm{C}$. Then color reagent was added and the mixture was further incubated for $20 \mathrm{~min}$ at room temperature. After that, $0.4 \mathrm{~N}$ $\mathrm{NaOH}$ was added and the absorbance was monitored at $505 \mathrm{~nm}$. Blood urea nitrogen levels were measured using a urease-indophenol method kit (Asan pharmaceutical, Hwaseong, Korea) as follows: the enzyme solution and the serum were co-incubated for $5 \mathrm{~min}$ at $37^{\circ} \mathrm{C}$. Then color reagent was added and the mixture was incubated for $10 \mathrm{~min}$ at $37^{\circ} \mathrm{C}$. The absorbance was measured at $580 \mathrm{~nm}$. All experiments and protocols for animal care were reviewed and approved by the Institutional Animal Care and Use Committee of Konkuk University (KU15046).

\subsection{Cytotoxicity of Phloretin against Mammalian Cells}

MRC-5 and HaCaT human keratinocytes were purchased from the American Type Culture Collection (Manassas, VA, USA). The 3-(4,5-dimethylthiazol-2-yl)2,5-diphenyl tetrazolium bromide (MTT) assay was used to assess the viability of MRC-5 and HaCaT cells exposed to phloretin $(0-400 \mu \mathrm{M})$. Cell viability was measured at $570 \mathrm{~nm}$ with a microplate reader and expressed as percentage values representing the mean of at least three independent experiments. 


\subsection{Construction, Expression, and Purification of $m t K A S I I I$}

The $f a b H$ gene encoding mtKASIII amplified from M. tuberculosis (H37Rv) genomic DNA was obtained from The Korean Institute of Tuberculosis (Seoul, Korea). The forward and reverse primers $5^{\prime}$-TAG GAC GCA TAT GAC GGA GAT CGC CAC- $3^{\prime}$ and $5^{\prime}$-CTG GCT GGA TCC GAT CTT CGC GCG CTC A-3' with NdeI and BamHI restriction sites, respectively, were used to amplify mtKASIII. Purified PCR products were first cloned into the pGEM-T-Easy vector (Promega, Madison, WI, USA) and mtKASIII fragments were inserted into $\mathrm{pET15b}$ via NdeI and BamHI sites to obtain pET-15b/mtKASIII, which was transformed into Escherichia coli BL21 (DE3) cells. Expression and purification of mtKASIII were carried out as described previously for Staphylococcus aureus KASIII protein [27].

\subsection{Fluorescence Quenching between mtKASIII Protein and Phloretin}

The binding constants of phloretin and mtKASIII protein were determined at $25{ }^{\circ} \mathrm{C}$ with an RF-5301PC spectrofluorophotometer (Shimadzu, Kyoto, Japan). Phloretin was titrated with $10 \mu \mathrm{M}$ mtKASIII protein solution in sodium phosphate buffer $(50 \mathrm{mM})$ containing $\mathrm{NaCl}(100 \mathrm{mM})$ at $\mathrm{pH}$ 8.0, with a protein-to-inhibitor ratio of 1:10. The samples were placed in a $2 \mathrm{~mL}$ cuvette and absorbance was measured with excitation and emission path lengths of $10 \mathrm{~nm}$. Fluorescence quantum yields of mtKASIII in the presence of increasing concentrations of phloretin were determined by measuring tryptophan emission. Detailed procedures are described in our previous report $[42,43]$.

\subsection{Docking Studies}

The X-ray crystallographic structure of free form mtKASIII (1M1M.pdb) was used to evaluate its binding with phloretin [44]. We defined the active site and considered receptor-substrate interactions. Computations were performed on a Linux platform using DS modeling/CDOCKER (Biovia, San Diego, CA, USA) and a CHARMM force field [43]. The algorithm assumed a rigid protein and permitted ligand flexibility. The final docking poses were refined by a minimization step. The results were reported as an energy term that included both protein-ligand interaction and internal ligand strain. A higher energy value indicates more favorable binding.

\subsection{Statistical Analyses}

At least three independent samples were included in each analysis. Data were analyzed using GraphPad InStat v.3.05 software (GraphPad Inc., La Jolla, CA, USA). Values were considered statistically significant at $p<0.05$.

\section{Conclusions}

Mycobacteria have a lipid-rich, highly impermeable cell wall that provides protection from most antibiotics. Phloretin is one of the natural occurring chalcones (1,3-diaryl-2-propen-1-ones) and has a flexible structure, which is presumed to enhance its membrane permeability. Some synthetic chalcones and their synthetic derivatives have demonstrated inhibitory activity against $M$. tuberculosis strain H37Rv in previous studies [45-49].

As shown in the binding model, phloretin can go deep into the active site of mtKASIII, resulting in hydrogen bonding with catalytic residue Cys122, as well as Asn261. This may cause the inhibition of mtKASIII, resulting in anti-tubercular activities of phloretin. The mechanism could be investigated by protein assays in future research. The Mycobacteria cell wall, which is essential for its survival, is lipid-rich and highly impermeable, providing protection from antibiotics and allowing the bacterium to persist and to proliferate in macrophages. From our current results, the flexible, open-chain structure of phloretin is the key factor for the membrane permeability against the Mycobacteria cell wall.

In this study, we showed that treatment with phloretin decreased IL-1 $\beta$, IL-6, IL-12, TNF- $\alpha$, and MMP-1 mRNA levels in IFN- $\gamma$-stimulated human lung fibroblast MRC- 5 cells, as well as LPS-stimulated dendritic cells. Mycobacteria activate signaling pathways involved in inflammation, 
including MAPK and NF- $\mathrm{KB}$ [50], and M. tuberculosis has been shown to induce MMP-1 expression in a signal transducer and activator of transcription 3/p38 MAPK/NF-kB-dependent manner, thereby stimulating collagen cleavage in human lung fibroblast MRC-5 cells [51]; these effects are attenuated by phloretin. The current data suggest that phloretin modulates the expression of pro-inflammatory cytokines via inhibition of p38 MAPK/ERK signaling. Phloretin may target ERK and p38 MAPK signaling downstream of IFN- $\gamma$. In vitro and in vivo blood tests in LPS-stimulated mouse models indicate that phloretin has minimal toxicity. By phloretin, the levels of the pro-inflammatory cytokines TNF- $\alpha$, IL-1 $\beta$, and IL- 6 were suppressed in lung homogenates from mice with LPS injection in vivo.

Though the $\mathrm{MIC}_{90}$ of phloretin is quite high for clinical purposes foods, such as apple, can be a promising dietary source of phloretin as an anti-TB molecule. Our in vivo and in vitro results showed that phloretin may be a safe and effective natural compound for the prevention of $\mathrm{TB}$, as well as lung inflammation.

Acknowledgments: This work was supported by the National Research Foundation of Korea (NRF) grant funded by the Korea government (MSIP-2016R1A2B2008543).

Author Contributions: Y.K. designed the research; Y.K., D.J., and H.N.J. wrote the paper; D.J. and C.K. performed the in vitro assays; D.J. and I.D.J. performed the in vivo assays; M.-C.J. studied the binding interaction with a target protein; S.R. measured the anti-TB activities.

Conflicts of Interest: The authors declare no conflict of interest.

\section{References}

1. Scalbert, A.; Manach, C.; Morand, C.; Rémésy, C.; Jiménez, L. Dietary Polyphenols and the Prevention of Diseases. Crit. Rev. Food Sci. Nutr. 2005, 45, 287-306. [CrossRef] [PubMed]

2. Hügel, H.M.; Jackson, N.; May, B.; Zhang, A.L.; Xue, C.C. Polyphenol protection and treatment of hypertension. Phytomedicine 2016, 23, 220-231. [CrossRef] [PubMed]

3. Croft, K.D. Dietary polyphenols: Antioxidants or not? Arch. Biochem. Biophys. 2016, 595, 120-124. [CrossRef] [PubMed]

4. Middleton, E.J.R.; Kandaswami, C.; Theoharides, T.C. The Effects of Plant Flavonoids on Mammalian Cells: Implications for Inflammation, Heart Disease, and Cancer. Pharmacol. Rev. 2000, 52, 673-751. [PubMed]

5. Escarpa, A.; González, M. High-performance liquid chromatography with diode-array detection for the determination of phenolic compounds in peel and pulp from different apple varieties. J. Chromatogr. A 1998, 823, 331-337. [CrossRef]

6. Tsao, R.; Yang, R.; Young, J.C.; Zhu, H. Polyphenolic Profiles in Eight Apple Cultivars Using High-Performance Liquid Chromatography (HPLC). J. Agric. Food Chem. 2003, 51, 6347-6353. [CrossRef] [PubMed]

7. Lommen, A.; Godejohann, M.; Venema, D.P.; Hollman, P.C.H.; Spraul, M. Application of Directly Coupled HPLC-NMR-MS to the Identification and Confirmation of Quercetin Glycosides and Phloretin Glycosides in Apple Peel. Anal. Chem. 2000, 72, 1793-1797. [CrossRef] [PubMed]

8. Bonarska-Kujawa, D.; Cyboran, S.; Oszmiański, J.; Kleszczyńska, H. Extracts from apple leaves and fruits as effective antioxidants. J. Med. Plants Res. 2011, 5, 2339-2347.

9. Crespy, V.; Aprikian, O.; Morand, C.; Besson, C.; Manach, C.; Demigné, C.; Rémésy, C. Bioavailability of phloretin and phloridzin in rats. J. Nutr. 2001, 131, 3227-3230. [PubMed]

10. Rezk, B.M.; Haenen, G.R.M.; van der Vijgh, W.J.; Bast, A. The antioxidant activity of phloretin: The disclosure of a new antioxidant pharmacophore in flavonoids. Biochem. Biophys. Res. Commun. 2002, 295, 9-13. [CrossRef]

11. Stangl, V.; Lorenz, M.; Ludwig, A.; Grimbo, N.; Guether, C.; Sanad, W.; Ziemer, S.; Martus, P.; Baumann, G.; Stangl, K. The flavonoid phloretin suppresses stimulated expression of endothelial adhesion molecules and reduces activation of human platelets. J. Nutr. 2005, 135, 172-178. [PubMed]

12. Chang, W.-T.; Huang, W.-C.; Liou, C.-J. Evaluation of the anti-inflammatory effects of phloretin and phlorizin in lipopolysaccharide-stimulated mouse macrophages. Food Chem. 2012, 134, 972-979. [CrossRef] [PubMed] 
13. Puupponen-Pimia, R.; Nohynek, L.; Meier, C.; Kahkonen, M.; Heinonen, M.; Hopia, A.; Oksman-Caldentey, K.-M. Antimicrobial properties of phenolic compounds from berries. J. Appl. Microbiol. 2001, 90, 494-507. [CrossRef] [PubMed]

14. Kim, W.S.; Kim, J.-S.; Cha, S.B.; Kim, H.; Kwon, K.W.; Kim, S.J.; Han, S.J.; Choi, S.Y.; Cho, S.-N.; Park, J.-H.; et al. Mycobacterium tuberculosis Rv3628 drives Th1-type T cell immunity via TLR2-mediated activation of dendritic cells and displays vaccine potential against the hyper-virulent Beijing $\mathrm{K}$ strain. Oncotarget 2016, 7, 24962-24982. [CrossRef] [PubMed]

15. Daffé, M.; Draper, P. The Envelope Layers of Mycobacteria with Reference to their Pathogenicity. Adv. Microb. Physiol. 1997, 39, 131-203.

16. Barry, C.E.; Lee, R.E.; Mdluli, K.; Sampson, A.E.; Schroeder, B.G.; Slayden, R.A.; Yuan, Y. Mycolic acids: Structure, biosynthesis and physiological functions. Prog. Lipid Res. 1998, 37, 143-179. [CrossRef]

17. Kremer, L.; Douglas, J.D.; Baulard, A.R.; Morehouse, C.; Guy, M.R.; Alland, D.; Dover, L.G.; Lakey, J.H.; Jacobs, W.R.; Brennan, P.J.; et al. Thiolactomycin and related analogues as novel anti-mycobacterial agents targeting KasA and KasB condensing enzymes in Mycobacterium tuberculosis. J. Biol. Chem. 2000, 275, 16857-16864. [CrossRef] [PubMed]

18. Price, A.C.; Choi, K.H.; Heath, R.J.; Li, Z.; White, S.W.; Rock, C.O. Inhibition of beta-ketoacyl-acyl carrier protein synthases by thiolactomycin and cerulenin: Structure and mechanism. J. Biol. Chem. 2001, 276, 6551-6559. [CrossRef] [PubMed]

19. Qiu, X.; Janson, C.A.; Konstantinidis, A.K.; Nwagwu, S.; Silverman, C.; Smith, W.W.; Khandekar, S.; Lonsdale, J.; Abdel-Meguid, S.S. Crystal structure of beta-ketoacyl-acyl carrier protein synthase III. A key condensing enzyme in bacterial fatty acid biosynthesis. J. Biol. Chem. 1999, 274, 36465-36471. [CrossRef] [PubMed]

20. Bloch, K. Control Mechanisms for Fatty Acid Synthesis in Mycobacterium Smegmatis. Adv. Enzymol. Relat. Areas Mol. Biol. 2006, 45, 1-84.

21. Cole, S.T.; Brosch, R.; Parkhill, J.; Garnier, T.; Churcher, C.; Harris, D.; Gordon, S.V.; Eiglmeier, K.; Gas, S.; Barry, C.E.; et al. Deciphering the biology of Mycobacterium tuberculosis from the complete genome sequence. Nature 1998, 393, 537-544. [CrossRef] [PubMed]

22. White, S.W.; Zheng, J.; Zhang, Y.-M.; Rock, C.O. The Structural biology of Type II fatty acid biosynthesis. Annu. Rev. Biochem. 2005, 74, 791-831. [CrossRef] [PubMed]

23. Brown, A.K.; Sridharan, S.; Kremer, L.; Lindenberg, S.; Dover, L.G.; Sacchettini, J.C.; Besra, G.S. Probing the mechanism of the Mycobacterium tuberculosis beta-ketoacyl-acyl carrier protein synthase III mtFabH: Factors influencing catalysis and substrate specificity. J. Biol. Chem. 2005, 280, 32539-32547. [CrossRef] [PubMed]

24. Choi, K.H.; Kremer, L.; Besra, G.S.; Rock, C.O. Identification and substrate specificity of beta-ketoacyl (acyl carrier protein) synthase III (mtFabH) from Mycobacterium tuberculosis. J. Biol. Chem. 2000, 275, 28201-28207. [PubMed]

25. Scarsdale, J.N.; Kazanina, G.; He, X.; Reynolds, K.A.; Wright, H.T. Crystal structure of the Mycobacterium tuberculosis beta-ketoacyl-acyl carrier protein synthase III. J. Biol. Chem. 2001, 276, 20516-20522. [CrossRef] [PubMed]

26. Liu, Y.; Zhong, W.; Li, R.-J.; Li, S. Synthesis of Potent Inhibitors of $\beta$-Ketoacyl-Acyl Carrier Protein Synthase III as Potential Antimicrobial Agents. Molecules 2012, 17, 4770-4781. [CrossRef] [PubMed]

27. Lee, J.-Y.; Jeong, K.-W.; Shin, S.; Lee, J.-U.; Kim, Y. Discovery of novel selective inhibitors of Staphylococcus aureus $\beta$-ketoacyl acyl carrier protein synthase III. Eur. J. Med. Chem. 2012, 47, 261-269. [CrossRef] [PubMed]

28. Jeong, K.-W.; Lee, J.-Y.; Kang, D.-I.; Lee, J.-U.; Shin, S.Y.; Kim, Y. Screening of Flavonoids as Candidate Antibiotics against Enterococcus faecalis. J. Nat. Prod. 2009, 72, 719-724. [CrossRef] [PubMed]

29. Bilenki, L.; Gao, X.; Wang, S.; Yang, J.; Fan, Y.; Han, X.; Qiu, H.; Yang, X. Dendritic Cells from Mycobacteria-Infected Mice Inhibits Established Allergic Airway Inflammatory Responses to Ragweed via IL-10- and IL-12-Secreting Mechanisms. J. Immunol. 2010, 184, 7288-7296. [CrossRef] [PubMed]

30. Fabiani, R.; Minelli, L.; Rosignoli, P. Apple intake and cancer risk: A systematic review and meta-analysis of observational studies. Public Health Nutr. 2016, 19, 2603-2617. [CrossRef] [PubMed]

31. Bao, M.-J.; Shen, J.; Jia, Y.-L.; Li, F.-F.; Ma, W.-J.; Shen, H.-J.; Shen, L.-L.; Lin, X.-X.; Zhang, L.-H.; Dong, X.-W.; et al. Apple polyphenol protects against cigarette smoke-induced acute lung injury. Nutrition 2013, 29, 235-243. [CrossRef] [PubMed] 
32. Jnawali, H.N.; Jeon, D.; Jeong, M.-C.; Lee, E.; Jin, B.; Ryoo, S.; Yoo, J.; Jung, I.D.; Lee, S.J.; Park, Y.-M.; et al. Antituberculosis Activity of a Naturally Occurring Flavonoid, Isorhamnetin. J. Nat. Prod. 2016, 79, 961-969. [CrossRef] [PubMed]

33. Collart, M.A.; Belin, D.; Vassalli, J.D.; de Kossodo, S.; Vassalli, P. Gamma interferon enhances macrophage transcription of the tumor necrosis factor/cachectin, interleukin 1, and urokinase genes, which are controlled by short-lived repressors. J. Exp. Med. 1986, 164, 2113-2118. [CrossRef] [PubMed]

34. Vila-del Sol, V.; Fresno, M. Involvement of TNF and NF- $\mathrm{BB}$ in the transcriptional control of cyclooxygenase-2 expression by IFN-gamma in macrophages. J. Immunol. 2005, 174, 2825-2833. [CrossRef] [PubMed]

35. Lin, P.L.; Ford, C.B.; Coleman, M.T.; Myers, A.J.; Gawande, R.; Ioerger, T.; Sacchettini, J.; Fortune, S.M.; Flynn, J.L. Sterilization of granulomas is common in active and latent tuberculosis despite within-host variability in bacterial killing. Nat. Med. 2013, 20, 75-79. [CrossRef] [PubMed]

36. Mattila, J.T.; Ojo, O.O.; Kepka-Lenhart, D.; Marino, S.; Kim, J.H.; Eum, S.Y.; Via, L.E.; Barry, C.E.; Klein, E.; Kirschner, D.E.; et al. Microenvironments in Tuberculous Granulomas Are Delineated by Distinct Populations of Macrophage Subsets and Expression of Nitric Oxide Synthase and Arginase Isoforms. J. Immunol. 2013, 191, 773-784. [CrossRef] [PubMed]

37. Flynn, J.L.; Chan, J.; Lin, P.L. Macrophages and control of granulomatous inflammation in tuberculosis. Mucosal Immunol. 2011, 4, 271-278. [CrossRef]

38. Mariotti, S.; Sargentini, V.; Pardini, M.; Giannoni, F.; De Spirito, M.; Gagliardi, M.C.; Greco, E.; Teloni, R.; Fraziano, M.; Nisini, R. Mycobacterium tuberculosis may escape helper T cell recognition by infecting human fibroblasts. Hum. Immunol. 2013, 74, 722-729. [CrossRef] [PubMed]

39. Park, Y.S.; Kang, J.-W.; Lee, D.H.; Kim, M.S.; Bak, Y.; Yang, Y.; Lee, H.G.; Hong, J.; Yoon, D.-Y. Interleukin-32 $\alpha$ downregulates the activity of the B-cell CLL/lymphoma 6 protein by inhibiting protein kinase C $\varepsilon$-dependent SUMO-2 modification. Oncotarget 2014, 5, 8765-8777. [CrossRef] [PubMed]

40. Lee, E.; Kim, J.-K.; Shin, S.; Jeong, K.-W.; Shin, A.; Lee, J.; Lee, D.G.; Hwang, J.-S.; Kim, Y. Insight into the antimicrobial activities of coprisin isolated from the dung beetle, Copris tripartitus, revealed by structure-activity relationships. Biochim. Biophys. Acta Biomembr. 2013, 1828, 271-283. [CrossRef] [PubMed]

41. Lee, E.; Jeong, K.-W.; Jnawali, H.; Shin, A.; Heo, Y.-S.; Kim, Y. Cytotoxic Activity of 3,6-Dihydroxyflavone in Human Cervical Cancer Cells and Its Therapeutic Effect on c-Jun N-Terminal Kinase Inhibition. Molecules 2014, 19, 13200-13211. [CrossRef] [PubMed]

42. Jnawali, H.N.; Lee, E.; Jeong, K.-W.; Shin, A.; Heo, Y.-S.; Kim, Y. Anti-inflammatory Activity of Rhamnetin and a Model of Its Binding to c-Jun $\mathrm{NH}_{2}$-Terminal Kinase 1 and p38 MAPK. J. Nat. Prod. 2014, 77, 258-263. [CrossRef] [PubMed]

43. Lee, J.; Jeong, K.-W.; Jin, B.; Ryu, K.-S.; Kim, E.-H.; Ahn, J.-H.; Kim, Y. Structural and Dynamic Features of Cold-Shock Proteins of Listeria monocytogenes, a Psychrophilic Bacterium. Biochemistry 2013, 52, 2492-2504. [CrossRef] [PubMed]

44. Musayev, F.; Sachdeva, S.; Neel Scarsdale, J.; Reynolds, K.A.; Wright, H.T. Crystal Structure of a Substrate Complex of Mycobacterium tuberculosis $\beta$-Ketoacyl-acyl Carrier Protein Synthase III (FabH) with Lauroyl-coenzyme A. J. Mol. Biol. 2005, 346, 1313-1321. [CrossRef] [PubMed]

45. Lin, Y.-M.; Zhou, Y.; Flavin, M.T.; Zhou, L.-M.; Nie, W.; Chen, F.-C. Chalcones and flavonoids as anti-Tuberculosis agents. Bioorg. Med. Chem. 2002, 10, 2795-2802. [CrossRef]

46. Moodley, S.; Koorbanally, N.A.; Moodley, T.; Ramjugernath, D.; Pillay, M. The 3-(4,5-dimethylthiazol-2-yl)-2, 5-diphenyl tetrazolium bromide (MTT) assay is a rapid, cheap, screening test for the in vitro anti-tuberculous activity of chalcones. J. Microbiol. Methods 2014, 104, 72-78. [CrossRef] [PubMed]

47. Ávila, H.P.; Smânia, E.F.A.; Monache, F.D.; Smânia, A. Structure-activity relationship of antibacterial chalcones. Bioorg. Med. Chem. 2008, 16, 9790-9794. [CrossRef] [PubMed]

48. Sivakumar, P.M.; Seenivasan, S.P.; Kumar, V.; Doble, M. Synthesis, antimycobacterial activity evaluation, and QSAR studies of chalcone derivatives. Bioorg. Med. Chem. Lett. 2007, 17, 1695-1700. [CrossRef] [PubMed]

49. Ventura, T.; Calixto, S.; de Azevedo Abrahim-Vieira, B.; de Souza, A.; Mello, M.; Rodrigues, C.; Soter de Mariz e Miranda, L.; Alves de Souza, R.; Leal, I.; Lasunskaia, E.; et al. Antimycobacterial and Anti-Inflammatory Activities of Substituted Chalcones Focusing on an Anti-Tuberculosis Dual Treatment Approach. Molecules 2015, 20, 8072-8093. [CrossRef] [PubMed] 
50. Hasan, Z.; Shah, B.H.; Mahmood, A.; Young, D.B.; Hussain, R. The effect of mycobacterial virulence and viability on MAP kinase signalling and TNF $\alpha$ production by human monocytes. Tuberculosis 2003, 83, 299-309. [CrossRef]

51. O'Kane, C.M.; Elkington, P.T.; Jones, M.D.; Caviedes, L.; Tovar, M.; Gilman, R.H.; Stamp, G.; Friedland, J.S. STAT3, p38 MAPK, and NF-кB Drive Unopposed Monocyte-Dependent Fibroblast MMP-1 Secretion in Tuberculosis. Am. J. Respir. Cell Mol. Biol. 2010, 43, 465-474. [CrossRef] [PubMed]

Sample Availability: Samples of the compounds are available from the authors.

(C) 2017 by the authors; licensee MDPI, Basel, Switzerland. This article is an open access article distributed under the terms and conditions of the Creative Commons Attribution (CC BY) license (http:/ / creativecommons.org/licenses/by/4.0/). 